\title{
Maternal Group Participation and Child Nutritional Status in Peru
}

\author{
September 14, 2017
}

\begin{abstract}
Using data from the Peruvian sample of the Young Lives study, this paper investigates the association between maternal group participation and child nutritional status at the ages of 1 and 5 years. This study finds that the relationship between child nutrition and maternal group participation depends on the level of maternal education. In fact, maternal group participation is positively associated with child height-for-age when children were 1 year old, for those children whose mothers had had no formal education. This same association fades at 5 years of age. Maternal group participation may affect child nutrition through a number of mechanisms. This paper provides suggestive evidence on the positive role that this participation might play in promoting better breastfeeding practice and a more secure mother-child bond and in easing mothers' access to additional resources and support.
\end{abstract}

Keywords: Group participation; child nutrition; Peru.

JEL Codes: I, I3, D1. 


\section{Introduction}

Nutritional status during early childhood is a major predictor of health conditions and economic outcomes in later stages of life (Case et al., 2005; Gertler and Boyce, 2001). This is the reason why policy interventions during early childhood have been found to be particularly cost-effective, with higher rates of return than later interventions (Heckman, 1995, 2000).

This paper studies the association between mothers' membership of community organizations in Peru and their children's nutritional status in the first years of life. Being a member of such a group may affect a mother's decisions about investments in her child health through a number of mechanisms. These are quite similar to those that the economic literature discusses as being relevant to maternal education (Glewwe, 1999), one of the strongest predictors of child health and nutritional status (Behrman and Deolalikar, 1990; and see Strauss and Thomas, 1995 for a review). First, group participation might facilitate the mother's acquisition of basic health knowledge, which might encourage better decisions, for example in terms of breastfeeding, vaccination and nutrition, as well as improving the mother's ability to prevent, recognize and treat child illnesses. The information-sharing might be a valuable resource, particularly for poorly educated mothers who did not have the chance to learn through schooling. Second, it might ease access to additional resources and health services. Third, there might be implications for maternal mental health and mother-child bonding as a result of the interaction with other mothers within the community.

I test the association between maternal group membership and child nutrition at ages 1 and 5 using the Peruvian sample from Young Lives, a longitudinal study of childhood poverty. I find evidence of a robust association between maternal group participation and child nutrition at the age of 1 . This same fades when the children were 5. Interestingly, this paper suggests that the relationship between child nutrition and maternal group membership depends on the level of maternal education, being (positive and) stronger for those children whose mothers had no education.

The most important caveat to this paper is that the results cannot be interpreted 
causally because of the self-selection into group membership. However, while potential omitted variable bias cannot be ruled out, the fact that our estimation controls for an extended set of characteristics at child, household and community level, suggests that the size of the omitted variable bias is unlikely to be large. The inclusion of community-level fixed effects rules out several potential threats to causal identification, for example related to the existence (or not) of community organizations where the mother and the child live. Still, the decision to be a member of a community organization is a voluntary one, and unobservable characteristics at child, mother and household level might drive both the mother's decision to participate and the child's nutritional status. Furthermore, this paper recognizes the potential for reverse causality to arise when the relationship between maternal group membership and child nutrition is examined. This issue is overcome by the use of longitudinal data, which help disentangle the temporal order between maternal group participation in the child's early years and the date when the child's nutritional status was measured.

Finally, the last section analyses the potential mechanisms through which the positive relationship found between maternal group participation and child nutrition might work. It provides suggestive evidence on the positive role that maternal group participation might play in easing mothers' access to additional resources and health services; in equipping poorly educated mothers with basic health knowledge which might encourage better breastfeeding practice; and in promoting a more secure mother-child bond.

\section{Conceptual framework}

The conceptual framework used in this paper fits into the general household production model according to which parents act to maximize a household utility function, subject to budget constraints and a child health production function (Behrman and Wolfe, 1987). The household's decisions about health and nutritional inputs reflect the household environment and characteristics, the child health endowments and the local community characteristics. 
In this section, we briefly discuss the main predictors of malnutrition in young children in developing countries, as emerging from the economic literature. The intention is not to provide a comprehensive review of the literature on child health and nutrition but to understand how a mother's group participation might play a role in improving her child's nutrition through some of the main predictors of child nutrition.

Living in poverty is certainly among the most recognized risk factors for child malnutrition. In fact, living in poverty places children at higher risk of growth retardation and malnutrition because of higher exposure to infections (mainly diarrhoeal diseases) and inadequate nutrition and access to health services (Martorell and Habicht, 1986). Evidence from Young Lives confirms that association (see for example Outes and Porter, 2013 and Schott et al., 2013). Through group participation a mother can benefit from a number of initiatives directly intended to help her and her new-born child by providing them with nutritious food, and medicine and health services. Enhanced access to additional resources and health services can obviously have a direct impact on child health and nutritional status.

Furthermore, beginning with the work of Caldwell (1979), a considerable body of research has recognized maternal education as a crucial factor in explaining differentials in child health and nutrition outcomes. The literature has widely discussed the different pathways through which maternal education is linked to child nutrition (see Glewwe, 1999 for a review). Improved socio-economic status is one of them (Currie, 2009). For example, more education might raise the household's income, either through higher wages or increased productivity in self-employment. A second pathway is related to knowledge about health. Education improves mothers' knowledge about good health practices and nutritional requirements as well as their ability to prevent, recognize and treat diseases. Through group participation and information-sharing, mothers with low levels of education might be able to learn some of those practices and acquire information that they did not get through formal education. This can subsequently affect their health behaviours, investment decisions and allocation of inputs.

Poor maternal mental health has been linked to infant malnutrition and reduced infant growth (Patel, 2000). Evidence from Young Lives suggests that children born to mothers who exhibited high levels of postnatal depressive symptoms were more likely to be 
stunted in infancy (Upadhyay and Srivastava, 2016; Harpham et al., 2005). Furthermore, poor maternal mental health has been linked to a reduced quality of mother-child interaction (Miranda et al., 2000). Social interaction through group participation might indeed alleviate some of the maternal depression symptoms (Seymour-Smith et al., 2017; Almedom, 2005) and improve the mother-child bonding.

In addition to maternal mental health, maternal physical health and child health endowment at birth are important for child development (Singh et al., 2017). Birth weight reflects the initial health of the child, which is known to affect future physical development strongly (Conley et al., 2003) and may reflect the poor health of the mother during pregnancy. There is a certain degree of intergenerational persistence in nutritional status, as maternal height is an important determinant of children's growth (Ramakrishnan et al., 1999). Maternal nutrition captures many aspects of the mother's background, reflecting the accumulated investments in health and inputs she has been exposed to during her lifetime, and, to some extent, genetic predisposition (Duflo, 2000; Subramanian et al., 2009).

Furthermore, the child's nutrition is influenced by a number of choices relating to the time use of his/her main caregiver (Behrman and Deolalikar, 1990). For example, maternal employment might affect a child health and nutrition negatively by reducing the time the mother has available for childcare (and increasing the opportunity cost of social participation), or positively via increased income.

Finally, another important confounding factor affecting household decisions and allocation of inputs is household composition, both in terms of size and age. The presence of other siblings in the household might affect how parents divide resources between their children, as the parents might display either compensating or reinforcing behaviours (Behrman et al., 1982).

\section{The Peruvian context}

Peru is a very interesting context in which to investigate the relationship between social participation and child malnutrition, given the high rate of both of these. In 2000, around the same period when the Young Lives Younger Cohort children were 
born, about 6 per cent of Peruvian newborns had a low birth weight and 25 per cent of children under 5 were stunted, with strong disparities between rural areas (where the rate was 40 per cent) and urban ones (13 per cent) (INEI, 2001).

The country has a longstanding tradition of social participation and contains a variety of intra-community and inter-community organizations. The latter usually take the form of federations acting as intermediaries between communities and regional or national organizations. An example is the federation of coffee-growers in the region of Cuzco (De Silva et al., 2005). The intra-community organizations, on the other hand, bring together people living in the same community to respond to collective needs, as in the case of the residents' associations and the self-defence committees (or rondas), or to meet the needs of the most vulnerable community members.

Women play a fundamental role in community organizations. In fact, many initiatives at community level are run by women. An example of these organizations is the women's groups, often subsidized by the government or by the nongovernmental sector and religious organizations. In both rural and urban areas, small groups of women gather in communal kitchens (or comedores populares) to provide food for free, or at a much reduced cost, to their families and the whole community. Another example is the mothers' clubs, which are self-organized groups of mothers who undertake a diverse range of activities, such as fundraising or skills training for their members, mainly supporting the initiatives of other organizations, nongovernmental organizations or government programmes in disadvantaged contexts (De Silva et al., 2005). Mothers' clubs often support initiatives geared toward improving children's health. This is the case with the Glass-of-milk programme, a welfare programme launched in 1984 with the objective of delivering milk and oats to the most vulnerable people in the community, primarily to children under 6 and pregnant or breastfeeding women. Another example is the Wawa Wasi day-care programme, which provides nurseries for children under 3 years old. The mothers in the community receive training in health care and nutrition and take turns at running the nurseries. 


\section{Data and descriptive statistics}

\subsection{Data}

This paper uses data from the Younger Cohort of the Peruvian sample from the Young Lives study. The study has been following two cohorts of children in four countries - Ethiopia, India (Andhra Pradesh and Telangana), Peru and Vietnam - for more than a decade. Five rounds of data have been collected so far, resulting in a unique individual-level panel dataset. In the present analysis, I use the first two rounds of data relating to the Younger Cohort, who were born in 2001/02 and were aged around 1 and 5 years old in 2002 (Round 1) and 2006 (Round 2) respectively. Almost 97 per cent of the children in the sample in 2002, and their caregivers, were interviewed in Round 2, making the attrition rate between the two data collection rounds about 3 per cent. The Younger Cohort sample consists of approximately 2,000 households, spread over 20 sentinel sites (or clusters) in different geographical regions. The sampling design purposively over-sampled poor areas. Therefore Young Lives is not representative at national level although it optimally reflects the diversity of children and families in Peru (Escobal and Flores, 2008).

The survey collects children's anthropometrics as well as extensive information about maternal characteristics, social capital and household-level characteristics. In Rounds 1 and 2 all information about the child was collected through face-to- ace interviews with the main caregiver, defined as 'the person in the household who can best answer questions about the [sampled] child'. For the purposes of this study, the sample is restricted to children whose main caregivers were their biological mothers. These represent more than 95 per cent of total cases.

\subsection{Group participation among mothers of Young Lives children}

In the Young Lives survey, information on maternal group participation was gathered in both Round 1 and Round 2, when children were about 1 year and 5 years old 
respectively. I define group participation as a variable equal to 1 if the mother had been a member of at least one of the following types of group in the past 12 months (and equal to 0 otherwise): work-related groups or trade unions, religious groups, community associations, cooperatives for saving or housing/credit/funeral, women's groups, communal kitchens or mothers' clubs, sports groups, peasants' organizations, groups for irrigation, security committees or political parties/ groups.

Given that the group participation refers to the past 12 months, for Round 1 data, mothers might have joined the organization just before the child was born or when the child was few months old, while in the joining period leading up to Round 2 , the child would have been about 4 years old.

Table 1 presents some descriptive statistics for maternal group participation in both rounds. Overall, 20 and 18 per cent of mothers were active members of at least one community group in Rounds 1 and 2 respectively. Although it is not possible to know when their membership started or ended or how long it lasted, a crosstabulation of membership in Rounds 1 and 2 suggests that group participation was more prevalent among mothers of newborns. Indeed while only 16 per cent of mothers joined at least one group between Rounds 1 and 2 (and were not members of any group in the 12 months preceding Round 1), a sizeable 73 per cent of members active in Round 1 had dropped out of their groups by Round 2.

Furthermore, mothers tended to participate in more groups when the child was 1 year old than when he/she was 5 years old. Among member mothers in Round 1, about 21 per cent were involved in two or more groups at the same time, while in Round 2 only 10 per cent of them had multiple memberships.

The most popular groups in both rounds were the women's groups (including the communal kitchens and the mothers' clubs) and the religious groups, which promoted a variety of both community-oriented and individual- ocused initiatives. 


\subsection{Group membership: push and pull factors}

The rest of this section looks at the (observable) characteristics of member mothers, to have a better understanding of what the push and pull factors into or out of group membership were in both Rounds 1 and 2. It is worth highlighting that participation was voluntary. Identifying what predicts maternal group membership is important in its own right for drawing a profile of member mothers. Further, it allows us to have a better understanding of what expectations mothers deciding to participate might have had.

The first set of characteristics we look at relates to the socio-economic status of the natal household. To the extent that participating in a community organization was seen as a way of getting access to resources or services and additional information, mothers with low education levels and living in poor households might have had more incentive to become members.

A second set of characteristics focuses on the opportunity cost of participating. These are mainly related to the mother's time use and other care responsibilities, and they include the household size, number and age composition of siblings and the mother's involvement in full-time paid activity.

A third set of characteristics relates to the mother's social integration in the community where she was living, and the extent to which there might have been barriers impeding her interaction with others in the community. In Round 2 Young Lives administered a module to measure the mother's sense of trust and belonging and her civic participation. The latter part captures to what extent the mother reached out to neighbours and the local authorities to address particular problems emerging in the community. I then add a dummy variable identifying those mothers whose native language was the same as the most commonly spoken language in the community, language being a potential barrier to engaging with community life.

Following the same line of thinking, I am controlling for maternal mental health as measured by the Self-Reporting Questionnaire (SRQ) 20, a screening tool capturing the number of symptoms of depression and anxiety that respondents had experienced 
in the previous 30 days. It is an empirical question whether mothers with poor mental health are more or less likely to be members of any community organization.

Finally, I control for some standard demographic characteristics, such as the ages of the child, mother and father and the gender of the child. ${ }^{1}$

Table 2 reports the predictors of maternal group participation, defined as being a member of at least one community group in Round 1 and/or Round 2. Taking into account all the characteristics reported above and controlling for unobservable characteristics common to all people living in the same community, mothers who were living in a household recently affected by economic or environmental shocks or family death were 26 per cent more likely to be members of a community organization when their child was 1 year old. Similarly, mothers from less wealthy households were more likely to be members of a community group in Round 2 . The decision to participate might indeed have been dictated by the need to access to safety net organizations (which operate through these community groups) (Nobles and Frankenberg, 2009).

The presence of younger siblings in the household was negatively associated with maternal membership, which might be due to a substitution between childcare time and the mother's free time for extra activities in the community.

It is interesting to observe that mothers who had a greater sense of community in the form of trust, social cohesion and perceptions of reciprocity were more likely to participate actively in community groups.

Finally, comparing mothers living in equally wealthy households, mothers with higher levels of education were more likely to become members, perhaps because a minimum level of education might be needed for a mother to be able and empowered enough to actively participate in community life. This interesting result and the implication of maternal education for child nutrition will be extensively discussed in the next sections.

\footnotetext{
${ }^{1}$ All variables included are described in detail in Table A1 in the Appendix.
} 


\subsection{Measures of malnutrition in Young Lives}

Anthropometric measures are often used to determine the extent of malnourishment among children. In this study, I use height- or-age as an indicator of child nutritional status (henceforth HAZ). This indicator is standardized according to age- and gender-specific child growth standards provided by the World Health Organization, which are universally comparable. Stunting, or low HAZ, is a measure of chronic malnutrition that is widely used in development economics (Alderman, 2000). The rationale for the use of HAZ is that a deficit in a child's HAZ is an indicator of cumulative deficient growth. Furthermore, it is less sensitive than weight- or-age and weight- or-height to temporary shocks due to morbidity and illnesses or seasonal variations in food availability.

In Table 3, I report the child's mean birth weight and length at birth, together with the HAZ and the proportion of stunted children at the ages of 1 year and 5 years. I compare the mean nutritional status of those children whose mothers were members of at least one community group and those whose mothers were not. Maternal group membership was measured in Round 1, when the child was 1 year old. Children whose mothers were poorly educated (with either no formal education or just primary education) and those whose mothers had either secondary or higher education are considered separately. These differences are reported alongside tests for statistical significance.

A few findings are notable. First, maternal education is positively related to children's health at birth and nutritional status at the ages of 1 and 5. In fact, the children of educated mothers are heavier and longer at birth and are less likely to be stunted at the ages of 1 and 5 regardless of maternal group membership. ${ }^{2}$ Second, children of member mothers tend to be bigger at birth, having a higher birth weight. Third, there is a positive correlation between group membership and child nutritional status at the age of 1 among children whose mothers had little education, and among

\footnotetext{
${ }^{2}$ Those differences are statistically significantly at the 95 per cent and 99 per cent confidence level (results not reported).
} 
them only. In fact, a lower proportion of them (37 per cent compared to 44 per cent) were stunted by the age of 1 . Conversely, no significant differences are found within the subgroups of children of educated mothers. Finally, there are no differences in nutritional indicators at the age of 5 .

\section{Empirical framework}

In this section, I briefly present the empirical framework used, highlighting implicit assumptions, limitations and threats to identification.

First of all, I investigate the predictors of child nutrition, looking at the association between the $H A Z_{i j t}$ of child $i$ living in community $j$ at time $t$ and maternal group membership $M_{i t}$ measured at the same time, as follows:

$$
H A Z_{i j t}=\boldsymbol{\gamma} \boldsymbol{X}_{i t}+\alpha_{0} M_{i t}+\boldsymbol{\varphi} \boldsymbol{E} \boldsymbol{d}_{i}+\boldsymbol{\delta} \boldsymbol{Z}_{i}+\omega_{j}+u_{i t}
$$

This specification relates a child's HAZ in period t (at either age 1 or age 5) to a vector of time-variant characteristics $\boldsymbol{X}_{i t}$; a broad set of time-invariant characteristics $\boldsymbol{Z}_{i}$; and maternal education $\boldsymbol{E} \boldsymbol{d}_{i}$. Maternal education is a vector of four dummy variables identifying those mothers with no formal education (used here as reference category), primary education only, secondary education and more than secondary education. Finally, $u_{i t}$ represents individual unobserved heterogeneity in health (or unobservable endowment) and $\omega_{j}$ is a set of community dummies to control for unobservable characteristics common at the community level, such as the availability and quality of health services in the community. ${ }^{3}$

The vectors $\boldsymbol{X}_{i t}$ and $\boldsymbol{Z}_{i}$ include observable health-relevant characteristics of the child (gender and birth weight), the parents (ethnicity, education and mother's height) and the household, both in terms of household composition (size, single-parent household, one-child household, siblings' age composition, and any member with

3 Standard errors are clustered at the community level. Communities refer to the 20 'clusters' as defined by Young Lives and described in Section 4.1. 
disabilities) and socio-economic status (wealth index, urban/rural location and a dummy for those households which suffered one or more shocks). $\boldsymbol{X}_{i t}$ also includes maternal employment status, which might have an effect on a child's nutritional status via an increased income or a reduction of the time the mother has available for childcare or group membership. Finally, I include the mother's sense of trust and belonging, her civic participation and a dummy for whether she speaks the community language, which might increase maternal group participation, as specified in Section 4.3.4

In equation 2 I then explore whether the overall correlation between child nutrition and maternal group participation varies across different levels of maternal education (heterogeneous specification), in contrast to equation 1, where the association is assumed to be constant and independent of the level of maternal education (homogeneous specification). The approach used is simple: I augment the basic regression specification by adding a set of interaction terms between the dummy for maternal group participation and the full set of dummy variables for maternal education, $E d_{i 0}, E d_{i 1}, E d_{i 2}$ and $E d_{i 3}$.

$$
\begin{aligned}
H A Z_{i j t}= & \boldsymbol{\gamma} \boldsymbol{X}_{i t}+\alpha_{0}\left(E d_{i 0} * M_{i t}\right)+, \ldots,+\alpha_{3}\left(E d_{i 3} * M_{i t}\right)+ \\
& \varphi_{1} E d_{i 1}+\varphi_{2} E d_{i 2}+\varphi_{3} E d_{i 3}+\delta Z_{i}+\omega_{j}+u_{i t}
\end{aligned}
$$

Assessing the causal contribution of maternal group participation to a child's nutritional status could entail serious problems of endogenous selection: there are systematic differences in the observable characteristics of member and non-member mothers and it is plausible that these may extend to unobservable characteristics. Although informative, an estimation of the child's nutrition equation would be unbiased only under very strong assumptions about the effect of unobservable characteristics on both a mother's decision to become a member and a child's nutritional status.

\footnotetext{
${ }^{4}$ Maternal trust and civic participation are included only in the specification for the child HAZ at the age of 1 as they are measured only in Round 1 .
} 
Further, as specified in both equation 1 and equation 2, maternal group participation and time-variant characteristics $\boldsymbol{X}_{i t}$ are measured at the same time as the dependent variable (contemporaneous specification). A potential concern is the reverse causality between child nutrition and maternal membership. Poor child nutrition could act as a pull factor if mothers seek help from the organizations operating in the community or as a push factor if mothers use the time they would have had for extra activities time on childcare. Nevertheless, the fact that maternal group participation refers to the 12 months before child height was measured alleviates potential reverse causality concerns.

Ultimately, in the absence of plausibly exogenous variations in the regressors, their estimation raises endogeneity concerns and might lead to biased interpretations. Therefore, the intention is not to identify causal effects. Rather, the estimated parameters should be interpreted as partial correlations that may reveal potential predictors of child nutrition, maternal group participation being one of them, as well as the channels through which such effects may be mediated. The multiplicity of individual- and household-level characteristics that I am able to measure, many of which are often unobserved, give a certain confidence about the robustness of the observed associations and alleviate biases that are due to endogeneity.

Furthermore, the assumptions behind the contemporaneous specification are that 'only contemporaneous inputs matter to the production of current achievements' or that these 'inputs are unchanging over time, so that current inputs capture the entire history of inputs' (Todd and Wolpin, 2003).5 To overcome the problem of either missing or incomplete information about past inputs, I also estimated a child's HAZ at the age of 5 as a function of lagged HAZ, measured at the age of 1 , and contemporaneous inputs, using a value-added approach:

$$
\begin{gathered}
H A Z_{i j t}=\boldsymbol{X} H A Z_{i j(t-1)}+\boldsymbol{X} \boldsymbol{X}_{i t}+ \\
\varphi_{1} E d_{i 1}+\varphi_{2} E{\stackrel{0}{d_{i 2}}{ }_{3}\left(E d_{i 0} * M_{i t} E d_{i 3}\right)+, \ldots,+}^{+}\left(E d_{i t}\right)+ \\
+
\end{gathered}
$$

5 I assume independence between the contemporaneous inputs and the potential unobserved endowment conditional on the control variables (in particular birth weight) (Todd and Wolpin, 2003). 
Even if the value-added approach is generally considered more powerful than contemporaneous specifications because it allows one to control for unobserved input history, it is susceptible to potential endogeneity bias, being the lagged value endogenous by construction (Todd and Wolpin, 2003).

Finally, I estimate the long-term correlation between maternal membership when children were aged $1(\mathrm{t}-1)$ and a child's HAZ at the age of $5(\mathrm{t})$, controlling for individual- and household-level characteristics at age $1 \boldsymbol{X}_{i(t-1)}$ and the set of timeinvariant characteristics $Z_{i}$, as specified below:

$$
\begin{gathered}
H A Z_{i j t}=\boldsymbol{\gamma} \boldsymbol{X}_{i(t-1)}+\alpha_{0}\left(E d_{i 0} * M_{i(t-1)}\right)+, \ldots,+\alpha_{3}\left(E d_{i 3} * M_{i(t-1)}\right)+ \\
\varphi_{1} E d_{i 1}+\varphi_{2} E d_{i 2}+\varphi_{3} E d_{i 3}+\delta Z_{i}+\omega_{j}+u_{i t}
\end{gathered}
$$

This model answers the question of whether maternal group participation during the first months of life is associated with child nutritional status at the age of 5 , net of the effect meditated through the observed variables.

\section{Results}

\subsection{Maternal group participation and child HAZ}

Table 4 reports the estimates of child HAZ at the ages of 1 (columns 1-2) and 5 (columns 3-5) using ordinary least squares and a fixed effect at community level.6 More specifically, columns 1 and 3 report the estimated parameters for the homogeneous specification (equation 1) for child HAZ at the ages of 1 and 5 respectively; similarly columns 2 and 4 report this for the heterogeneous specification (equation 2). In column 5 I report the results of the value-added approach for the child's HAZ at the age of 5

${ }^{6}$ See Table A2 in the Appendix for full results. 
(equation 3). Finally, in column 6 the long-term correlation between maternal group participation when the child was 1 year old and the child's HAZ at the age of 5 are reported (equation 4).

A number of findings are striking. First, overall maternal group participation is not significantly correlated with the child's HAZ at either age 1 or age 5 (Table 4, columns 1 and 3). Second, the correlation between maternal group participation and the child's HAZ at the age of 1 varies significantly across maternal education (Table 4, columns 2). Indeed, this heterogeneity seems to be sizeable, the correlation between maternal group participation and the child's HAZ at the age of 1 being positive and statistically significant only among those children whose mothers had no formal education. Third, this association remains robust when controlling for unobservable characteristics at community level. Nevertheless, although the inclusion of community fixed effects does not change the results qualitatively, it tends to lower the point estimates in the child HAZ equation (result not reported). This suggests some role for unobserved community heterogeneity in explaining child nutritional status and possibly maternal group participation and its association with child HAZ. ${ }^{7}$

Remarkably, the correlation between the child HAZ and group participation among the mothers who had no formal education is the same in magnitude as the correlation with maternal education, certainly one of the strongest predictors of child nutritional status. In fact, children whose mothers had completed primary education were 0.428 standard deviations taller than comparable children of the same age and gender whose mothers had had no formal education. For a child aged 11 months, this corresponds to 1.1 centimetre taller. The same difference in height $(0.431$ standard deviations) is found when comparing children of the same age whose mothers had had no formal education but were members of at least one community organization and children whose mothers had the same educational level but did not participate in any community group.

Among the other confounding factors, household composition matters. After

\footnotetext{
${ }^{7}$ A Hausman test, comparing the estimated parameters for the fixed-and random-effect models, suggests that there are systematic differences between the two sets of estimates, in favour of the fixed-effect model.
} 
household size was controlled for, living in a household with other children and adolescents significantly reduced child nutritional status, which presumably indicates that children had to compete for their share of resources. Notably, those children whose mothers were employed full-time had higher HAZ, which suggests that the positive income effect compensated for the potential negative effect of reduction of childcare time.

Other estimated parameters have expected signs. Birth weight, as an indicator of prenatal deprivation, is a strong predictor of a child HAZ at the age of 1 . Similarly, the mother's height is highly significant (positively). Finally, children living in a household where at least one household member had a mental or physical disability were worseoff.

The inclusion of different socio-economic indicators (wealth index, rural/ urban location and parents' education) in the same regression together with the mother's height (which is positively correlated with household welfare) can result in collinearity. To assess this possible problem, regressions dropping each one of the variables were estimated; the parameters were not significantly altered.

As reported in columns 4 and 5, there is no evidence of a statistically significant association between maternal group participation when the child was 5 years old and a child HAZ measured at the same age. Indeed, this result holds when controlling for lagged $\mathrm{HAZ}$ at the age of 1 , capturing potential missing or incomplete data on past inputs. As expected, child HAZ at the age of 1 is a strong predictor of the child's nutritional status at the age of $5 .{ }^{8}$ Furthermore, as for the age $1 \mathrm{HAZ}$ model, mother's height is positively correlated with child HAZ at the age of 5. Similarly, older children, girls and children living in richer households had higher HAZ at the age of 5. Finally, paternal education, which is indeed likely to affect child nutrition positively, via increased income, is positively correlated with $\mathrm{HAZ}$ at the age of 5.

Finally, in column 6 of Table 4, I report the long-term association between maternal group memberships measured in Round 1 and HAZ at the age of 5. Although the A test for stationarity suggests that the estimated coefficient for lagged HAZ at age 1 is statistically different from 1 at the 99 per cent confidence level. 
correlation is positive among mothers with no formal education, it is not statistically significant. In other words, maternal membership when the child was 1 year old is not directly correlated to a child HAZ at the age of 5. Nevertheless, the lack of a significant correlation between a mother's group membership when her child was 1 year old and a child HAZ at 5 does not necessarily mean that the real gains in linear growth found at the age of 1 disappear by the age of 5. Conversely, this result might reflect the cumulative nature of HAZ, maternal group participation in the first year of child's life being positively correlated with child HAZ at the age of 1, which in turn is a strong predictor of child HAZ at the age of 5, as shown in the value-added estimates.

Thinking about the technology of child health formation and the potential channels through which the relationship between maternal group participation and child nutrition might work, sheds some light on why a mother's group participation early in child's life might be more effective in improving child nutritional status during the first months of life than at later stages. Although, as emphasized above, this paper does not attempt a fully developed causal analysis of the mechanisms behind the correlation found, a number of potential pathways are discussed in the next section.

\subsection{Exploring the mechanisms behind the relation between maternal group participation and child nutrition}

In Section 2 we discussed the main predictors of child health and nutritional status and how maternal group participation could affect child health and nutrition indirectly through them. This section explores how the three main mechanisms identified (information-sharing; enhanced access to additional resources and health services; improved maternal mental health and motherchild bonding) can be tested using Young Lives data.

The first one is information-sharing. As discussed, active participation in community organizations, many of them run by women, and their initiatives might facilitate the 
acquisition of useful information and health knowledge, both valuable resources, particularly to uneducated mothers. More knowledge and better information might affect mothers' behaviours and their preferences and investments relevant to child health (De Silva and Harpham, 2007; Durlauf and Fafchamps, 2004). Round 1 data contain information about breastfeeding and vaccinations and, more specifically, for how long the child had been breastfed and whether he/she had been immunized against tuberculosis, measles and poliomyelitis. Unfortunately, it is not possible to know for how long the child had been exclusively breastfed or whether the mother had been feeding him/her with solid or with liquid food other than maternal milk.

The second potential mechanism is related to the additional resources and services the member mother might have had access to, either provided directly by the community organization she was a member of or by her extended network. Indeed, some community organizations might run initiatives intended to help mothers with new-born children. Further, being a member of a community organization might ease a mother's access to services, assets and other forms of support available within her network. Young Lives data contain information about 'any emotional help, economic help or assistance' the mother received in the previous 12 months. For member mothers this might include both internal support, received directly from the organization they were part of, and external support, which was accessible thorough their own network and for which being a member was not a requirement, or a combination of the two. Conversely, non-member mothers will only have had access to external support.

The third potential mechanism is related to maternal mental health. As mentioned, poor maternal mental health has been found to be linked to infant malnutrition and reduced infant growth and it is likely to affect the quality of mother-child interactions. Besides SRQ-20 capturing any symptoms of maternal depression and anxiety, Young Lives also collected information about mother-child bonding. More specifically, the interviewer asked the mother about what she did and how she reacted when the child did not stop crying. The indicator we constructed identifies to what extent the mother tuned into and responded to her child's cries and distress in a warm and sensitive way. A positive score signals more attentive childcare and a more secure 
mother-child bond.

Table 5 presents to what extent member mothers differ from non-member mothers in each of these indicators. Mean values are reported alongside t-tests for statistical significance of difference in means between the two groups.

First, the proportion of children who received full immunization is the same regardless of maternal group participation. Conversely, there are significant differences in all the other potential mechanisms. Member mothers breastfed for a longer period (about 11.2 months against 10.9 months). Second, member mothers were more likely to have access to support than non-members. On average about 85 per cent of member mothers had received (external) support at least once in the previous 12 months compared to 66 per cent of the non-member mothers. Among member mothers who received support, about 31 per cent received exclusively external support while 54 per cent received only internal support or a combination of the two. Third, member mothers seemed to respond to their children's cries and distress in a warmer and more sensitive way. Quite surprisingly, member mothers reported slightly more symptoms of anxiety and depression than non-member mothers.

I test these potential pathways, augmenting equation 2 for child HAZ at the age of 1 , by adding the indicators described above one at time. An alternative approach would be to consider distinct group memberships and use the different nature and type of initiatives promoted by each community to understand better the channels through which maternal participation might affect child nutrition. Unfortunately, this is not feasible for three main reasons: first, the sample of member mothers is relatively small; second, the availability of information on the nature of the activities promoted by each type of community organization is limited; third, in most cases the organizations promote a variety of initiatives, which likely affect child nutrition through multiple channels.

Two issues are explored. First, is there a positive and significant association between the potential mechanisms and a child's nutritional status? Second, does augmenting this regression reduce the estimated parameter for maternal group participation among mothers with no formal education? As reported in Table 6, I find that being 
breastfed for longer and receiving support are positively correlated with a child HAZ at the age of 1 . Nevertheless, it is not clear whether maternal group participation does operate through any of these mechanisms. ${ }^{9}$ Indeed, after controlling for them, the correlation between maternal group participation and a child HAZ remains substantially invariant, which suggests that these are not the main channels through which the correlation works.

Although, the descriptive statistics in Table 5 provide suggestive evidence on the positive role that maternal group participation might play in promoting a more attentive parenting style and better breastfeeding practice and in easing access to additional resources, the mechanisms behind the positive relationship found with child nutrition cannot be convincingly established within the confines of this paper.

\section{Conclusions}

This analysis provides suggestive evidence of a positive association between maternal group membership and child nutritional status. According to my findings, an 11month-old child whose mother had no formal education but was a member of at least one community organization was 1.1 centimetres taller than a child whose mother had the same educational level but did not participate in any community group. This positive correlation is quite sizeable considering that it is equivalent to the correlation with maternal education, one of the most important determinants of child health.

The most important caveat to this paper is that the results cannot be interpreted causally, mainly because of self-selection problems arising from the non-random assignment into membership. However, the multiplicity of individual- and household-level characteristics included in the analysis, and the fact that the results are robust when unobservable characteristics at community level are controlled for, give a certain confidence about the robustness of the observed associations and alleviate biases due to endogeneity.

\footnotetext{
${ }^{9}$ See Table A3 in the Appendix for full results.
} 
In exploring the mechanisms through which the correlation between maternal membership and child HAZ might operate, I found that member mothers were more likely to breastfeed for a longer period, to have access to additional resources and to be more able to tune into their children's emotional needs. However, no single one of the explored mechanisms stands out clearly as a major pathway. The relatively small sample of joiners and the limited information collected on the nature of the community organizations, limited the scope of the analysis of the potential pathways.

The evidence presented in this paper has main two implications. First, it reiterates the importance of maternal education for a child's nutrition and strengthens the existing calls for investment in female education. Second, it suggests that facilitating cooperation and association at the community level might help mothers with low levels of education to bring up healthy children. Future research should exploit experimental settings where parental participation in social activities and membership of community groups are arguably exogenous. 


\section{References}

Alderman, H. (2000). Anthropometry, Volume 1. In P. Glewwe and M. Grosh Designing Household Survey Questionnaires for Developing Countries.

Almedom, A. (2005). Social capital and mental health: an interdisciplinary review of primary evidence. Social Science \& Medicine 61(5), 943-964.

Behrman, J. R. and A. B. Deolalikar (1990). The intrahousehold demand for nutrients in rural south india: Individual estimates, fixed effects, and permanent income. The Journal of Human Resources 25 (4), 665-696.

Behrman, J. R., R. A. Pollak, and P. Taubman (1982). Parental preferences and provision for progeny. Journal of Political Economy 90 (1), 52-73.

Behrman, J. R. and B. L. Wolfe (1987). How does mother's schooling affect family health, nutrition, medical care usage, and household sanitation? Journal of Econometrics 36, 185-204.

Caldwell, J.C. (1979). Education as a factor in mortality decline: an examination of Nigerian data. Population Studies 33 (3), 395-413

Case, A., A. Fertig, and C. Paxson (2005). The lasting impact of childhood health and circumstance. Journal of health economics 24 (2), 365-389.

Conley, D., K. Strully, and N. Bennett (2003). The starting gate: birth weight and life chances. University of California Press.

Currie, J. (2009). Healthy, Wealthy and Wise: Socioeconomic Status, Poor Health in Childhood and Human Capital Development. Journal of Economic Literature 47 (1), 87-122.

De Silva, M. and T. Harpham (2007). Maternal social capital and child nutritional status in four developing countries. Health \& Place 13 (2), 341-355.

De Silva, M. J., T. Harpham, S. Huttly, R. Bartolini, and M. Penny (2005). Understanding sources and types of social capital in Peru. Community Development Journal 42 (1), 19-33.

Duflo, E. (2000). Grandmothers and granddaughters: old age pension and intrahousehold allocation in South Africa. World Bank Economic Review 17 (1), 1-25. 
Durlauf, S. and M. Fafchamps (2004). Social capital. The Centre for the Study of African Economies Working Paper Series (No. 214).

Escobal, J. and E. Flores (2008). An Assessment of the Young Lives Sampling Approach in Peru. Young Lives Technical Note 3.

Gertler, P. and S. Boyce (2001). An experiment in incentive-based welfare: the impact of Progresa on health in Mexico. University of California, Berkeley, 30-37.

Glewwe, P. (1999). Why does mother's schooling raise child health in developing countries? evidence from Morocco. Journal of Human Resources 34 (1), 124-159.

Harpham, T., S. Huttly, M. J. De Silva, and T. Abramsky (2005). Maternal Mental Health and Child Nutritional Status in Four Developing Countries. Journal of Epidemiology and Community Health 59 (12), 1060-1064.

Heckman, J. (1995). Lessons from the bell curve. Journal of Political Economy 103 (5), 1091-1120.

Heckman, J. (2000). Policies to foster human capital. NBER Working Papers No. 7288 .

INEI (2001). Encuesta demografica y de salud familiar, ENDES.

Martorell, R. and J.-P. Habicht (1986). Growth in early childhood in developing countries, in Human Growth: A Comprehensive Treatise (Vol 3). Ed. Frank Falkner and J.M. Tanner, Plenum Press.

Miranda, C., C. Paula, L. Santos, F. Nobrega, K. Hundeide, and J. Orley (2000). Association between mother-child interaction and health among mothers of malnourished children. Journal of Tropical Paediatrics 46, 314.

Nobles, J. and E. Frankenberg (2009). Mothers' community participation and child health. Journal of Health and Social Behavior 50 (1), 16-30.

Outes, I. and C. Porter (2013). Catching up from Early Nutritional Deficits? Evidence from Rural Ethiopia. Economics \& Human Biology 11 (2): 148-63.

Patel, V. (2000). Postnatal depression and infant growth and development in low income countries: a cohort study from Goa, India. Archives of Disease in Chilhood $88,34-7$.

Ramakrishnan, U., R. Martorell, D. G. Schroeder, and R. Flores (1999). Role of intergenerational effects on linear growth. The Journal of Nutrition 129 (2S), 544S-549S. 
Schott, W. B., B. T. Crookston, E. A. Lundeen, A. D. Stein and J. R. Behrman (2013). Periods of Child Growth up to Age 8 Years in Ethiopia, India, Peru and Vietnam: Key Distal Household and Community Factors. Social Science and Medicine 97, 278-87.

Seymour-Smith, M., T. Cruwys, A. Haslam and W. Brodribb (2017). Loss of group memberships predicts depression in postpartum mothers. Social Psychiatry and Psychiatric Epidemiology 52 (2), 201-210.

Singh, A., A.K. Upadhyay and K. Kumar (2017). Birth Size, Stunting and Recovery from Stunting in Andhra Pradesh, India: Evidence from the Young Lives Study. Maternal and Child Health Journal 21 (3): 492-508.

Strauss, J. and D. Thomas (1995). Human resources: Empirical modeling of household and family decisions. 3, Part 1, 1883-2023.

Subramanian, S. V., L. K. Ackerson, G. Davey Smith, John N.A (2009). Association of maternal height with child mortality, anthropometric failure, and anemia in India. The Journal of the American Medical Association, 301(16), 1691-1701.

Todd, P. and K. Wolpin (2003). On the specification and estimation of the production function for cognitive achievement. The Economic Journal 113 (485), F3-F33.

Upadhyay, A. K. and S. Srivastava (2016). Effect of Pregnancy Intention, Postnatal Depressive Symptoms and Social Support on Early Childhood Stunting: Findings from India. BioMed Central Pregnancy and Childbirth 16 (1): 107. 


\section{Tables}

Table 1: Maternal group participation

\begin{tabular}{lcccc}
\hline & \multicolumn{2}{c}{ Round 1 } & \multicolumn{2}{c}{ Round 2} \\
& Mean & Obs & Mean & Obs \\
\hline Member of at least 1 community group & 0.20 & 2051 & 0.18 & 2052 \\
No. of memberships (member mothers only) & & & & \\
1 membership & 0.79 & 415 & 0.9 & 376 \\
2 memberships & 0.17 & 415 & 0.09 & 376 \\
3 or more memberships & 0.04 & 415 & 0.01 & 376 \\
Members by type of group & & & & \\
Work-related/ trade union & 0.01 & 415 & 0.09 & 376 \\
Community association/ co-op & 0.27 & 415 & 0.04 & 376 \\
Women's group/ communal kitchen/ mothers' club & 0.36 & 415 & 0.55 & 376 \\
Political party or group & 0.08 & 415 & 0.02 & 376 \\
Religious group & 0.29 & 415 & 0.11 & 376 \\
Co-op for saving/housing/credit/ funeral group & 0.01 & 415 & 0.01 & 376 \\
Sports group & 0.06 & 415 & 0.01 & 376 \\
Other groups & 0.18 & 415 & 0.25 & 376 \\
\hline
\end{tabular}

Note: Maternal group participation is defined by a dummy equal to 1 if the mother is a member of one or more community group and 0 otherwise. The 'other groups' category includes peasant organizations and groups for irrigation or assistance against delinquencies, among others. 
Table 2: Predictors of maternal group membership

\begin{tabular}{|c|c|c|c|c|}
\hline & \multicolumn{2}{|c|}{ Round 1} & \multicolumn{2}{|c|}{ Round 2} \\
\hline & Coef. & Std. Error & Coef. & Std. Error \\
\hline \multicolumn{5}{|l|}{ Child } \\
\hline Age (in months) & 0.04 & $(0.07)$ & 0.14 & $(0.25)$ \\
\hline Age squared & -0.00 & $(0.00)$ & -0.00 & $(0.00)$ \\
\hline Birth weight (kg) & $0.27 * * *$ & $(0.09)$ & -0.05 & $(0.11)$ \\
\hline Gender & -0.01 & $(0.10)$ & 0.04 & $(0.09)$ \\
\hline \multicolumn{5}{|l|}{ Mother } \\
\hline Ethnicity: white & 0.14 & $(0.14)$ & -0.14 & $(0.28)$ \\
\hline Ethnicity: Other & 0.22 & $(0.42)$ & -0.07 & $(0.29)$ \\
\hline Education: Primary & $0.63 * *$ & $(0.28)$ & 0.13 & $(0.18)$ \\
\hline Education: Secondary & $0.68^{* *}$ & $(0.34)$ & $0.44^{*}$ & $(0.24)$ \\
\hline Education: > Secondary & $0.90^{* * *}$ & $(0.35)$ & $0.59 * *$ & $(0.25)$ \\
\hline Age (in years) & -0.03 & $(0.08)$ & 0.05 & $(0.06)$ \\
\hline Employed full time & -0.06 & $(0.30)$ & -0.11 & $(0.11)$ \\
\hline Speaks community language & -0.21 & $(0.15)$ & -0.15 & $(0.15)$ \\
\hline Good mental health & -0.00 & $(0.01)$ & 0.01 & $(0.01)$ \\
\hline Trust & $0.13 * *$ & $(0.06)$ & 0.06 & $(0.04)$ \\
\hline Civic participation & $0.25 * * *$ & $(0.04)$ & $0.11^{* * *}$ & $(0.04)$ \\
\hline \multicolumn{5}{|l|}{ Father } \\
\hline Education: Primary & 0.57 & $(0.47)$ & -0.06 & $(0.38)$ \\
\hline Education: Secondary & 0.61 & $(0.43)$ & -0.00 & $(0.36)$ \\
\hline Education: > Secondary & 0.44 & $(0.46)$ & 0.01 & $(0.33)$ \\
\hline Age & $0.06^{*}$ & $(0.04)$ & $0.18^{* *}$ & $(0.08)$ \\
\hline \multicolumn{5}{|l|}{ Household characteristics } \\
\hline Wealth index & -0.26 & $(0.40)$ & $-1.27 * * *$ & $(0.26)$ \\
\hline Urban & -0.16 & $(0.20)$ & -0.15 & $(0.15)$ \\
\hline Any shocks & $0.26^{* * *}$ & $(0.09)$ & 0.13 & $(0.08)$ \\
\hline One-child household & -0.18 & $(0.17)$ & $-0.23 *$ & $(0.13)$ \\
\hline Household size & 0.00 & $(0.03)$ & -0.01 & $(0.03)$ \\
\hline N. of children aged $\leq 2$ & $-0.28 * *$ & $(0.13)$ & -0.07 & $(0.08)$ \\
\hline N. of $2<$ children aged $\leq 5$ & 0.02 & $(0.10)$ & $-0.22 * * *$ & $(0.08)$ \\
\hline N. of $5<$ children aged $\leq 14$ & $0.09^{*}$ & $(0.05)$ & -0.05 & $(0.04)$ \\
\hline $\begin{array}{l}\text { Household member with } \\
\text { disability }\end{array}$ & -0.04 & $(0.13)$ & -0.17 & $(0.12)$ \\
\hline Observations & 1329 & & 1337 & \\
\hline $\mathrm{R}$-squared & 0.16 & & 0.09 & \\
\hline
\end{tabular}

Note: Probit with fixed effects at community level. Marginal effects reported. Standard errors reported in parentheses, clustered at community level. ${ }^{*} 0.1$, $* * 0.05, * * * 0.01$. Mothers with no formal education as reference category. 
Table 3: Child anthropometric indicators by maternal group membership and education

\begin{tabular}{|c|c|c|c|c|c|c|c|c|c|c|}
\hline & \multicolumn{9}{|c|}{ Mother } & \multirow{4}{*}{$\begin{array}{l}\text { t-test } \\
\text { p-value }\end{array}$} \\
\hline & \multicolumn{5}{|c|}{ No education or only primary education } & \multicolumn{4}{|c|}{ More than primary education } & \\
\hline & \multicolumn{2}{|c|}{ Not a member } & \multicolumn{2}{|c|}{ Member } & \multirow{2}{*}{$\begin{array}{r}\mathrm{t} \text {-test } \\
\mathrm{p} \text {-value }\end{array}$} & \multicolumn{2}{|c|}{ Not a member } & \multicolumn{2}{|c|}{ Member } & \\
\hline & Mean & Std.Dev & Mean & Std.Dev & & Mean & Std.Dev & Mean & Std.Dev & \\
\hline \multicolumn{11}{|l|}{ Child } \\
\hline \multicolumn{11}{|l|}{ At birth } \\
\hline Weight (kg) & 3.07 & 0.020 & 3.24 & 0.049 & 0.000 & 3.25 & 0.017 & 3.35 & 0.035 & 0.015 \\
\hline Length $(\mathrm{cm})$ & 49.29 & 0.147 & 48.75 & 0.369 & 0.130 & 49.46 & 0.129 & 49.69 & 0.250 & 0.435 \\
\hline \multicolumn{11}{|c|}{ At 1 year old } \\
\hline HAZ & -1.81 & 0.047 & -1.69 & 0.101 & 0.228 & -0.89 & 0.042 & -0.95 & 0.088 & 0.550 \\
\hline Stunted & 0.44 & 0.018 & 0.37 & 0.036 & 0.080 & 0.16 & 0.012 & 0.17 & 0.025 & 0.782 \\
\hline \multicolumn{11}{|c|}{ At 5 years old } \\
\hline HAZ & -2.11 & 0.042 & -2.04 & 0.080 & 0.449 & -1.09 & 0.035 & -1.20 & 0.069 & 0.176 \\
\hline Stunted & 0.50 & 0.019 & 0.49 & 0.037 & 0.830 & 0.17 & 0.013 & 0.19 & 0.026 & 0.356 \\
\hline
\end{tabular}

Note: Maternal group membership is measured at Round 1. Mean values and standard deviations (in parentheses) are reported alongside tests for statistical significance of differences in mean. 
Table 4: Child HAZ at the ages of 1 and 5

\begin{tabular}{|c|c|c|c|c|c|c|}
\hline & \multicolumn{2}{|c|}{ HAZ at age 1} & \multicolumn{4}{|c|}{ HAZ at age 5} \\
\hline & (1) & (2) & (3) & (4) & (5) & (6) \\
\hline $\begin{array}{l}\text { Member of at least one } \\
\text { organization }\end{array}$ & $\begin{array}{l}-0.067 \\
(0.089)\end{array}$ & & $\begin{array}{l}-0.005 \\
(0.054)\end{array}$ & & & \\
\hline Mother's educ: No educ. ${ }^{*}$ member & & $\begin{array}{c}0.431 * * \\
(0.196)\end{array}$ & & $\begin{array}{l}-0.135 \\
(0.093)\end{array}$ & $\begin{array}{l}-0.242 \\
(0.163)\end{array}$ & $\begin{array}{c}0.075 \\
(0.165)\end{array}$ \\
\hline Mother's educ: Primary*member & & $\begin{array}{l}-0.080 \\
(0.142)\end{array}$ & & $\begin{array}{l}-0.037 \\
(0.088)\end{array}$ & $\begin{array}{c}0.006 \\
(0.082)\end{array}$ & $\begin{array}{l}-0.073 \\
(0.082)\end{array}$ \\
\hline $\begin{array}{l}\text { Mother's educ: } \\
\text { Secondary*member }\end{array}$ & & $\begin{array}{l}-0.148 \\
(0.112)\end{array}$ & & $\begin{array}{c}0.010 \\
(0.079)\end{array}$ & $\begin{array}{c}0.028 \\
(0.076)\end{array}$ & $\begin{array}{l}-0.133 \\
(0.080)\end{array}$ \\
\hline $\begin{array}{l}\text { Mother's educ: } \\
\text { >Secondary*member }\end{array}$ & & $\begin{array}{c}0.021 \\
(0.213)\end{array}$ & & $\begin{array}{c}0.072 \\
(0.104)\end{array}$ & $\begin{array}{c}0.064 \\
(0.089)\end{array}$ & $\begin{array}{l}-0.094 \\
(0.187)\end{array}$ \\
\hline Mother's educ: Primary & $\begin{array}{c}0.344 \\
(0.212)\end{array}$ & $\begin{array}{l}0.428^{*} \\
(0.229)\end{array}$ & $\begin{array}{c}0.100 \\
(0.137)\end{array}$ & $\begin{array}{c}0.082 \\
(0.146)\end{array}$ & $\begin{array}{l}-0.035 \\
(0.101)\end{array}$ & $\begin{array}{c}0.222 \\
(0.139)\end{array}$ \\
\hline Mother's educ: Secondary & $\begin{array}{c}0.353 \\
(0.226)\end{array}$ & $\begin{array}{l}0.454^{*} \\
(0.236)\end{array}$ & $\begin{array}{l}0.273^{*} \\
(0.139)\end{array}$ & $\begin{array}{c}0.245 \\
(0.151)\end{array}$ & $\begin{array}{l}0.127 \\
(0.097)\end{array}$ & $\begin{array}{l}0.400 * * \\
(0.149)\end{array}$ \\
\hline Mother's educ: > Secondary & $\begin{array}{c}0.405 \\
(0.280)\end{array}$ & $\begin{array}{c}0.468 \\
(0.292)\end{array}$ & $\begin{array}{c}0.258 \\
(0.159)\end{array}$ & $\begin{array}{c}0.217 \\
(0.177)\end{array}$ & $\begin{array}{c}0.082 \\
(0.136)\end{array}$ & $\begin{array}{l}0.356^{* *} \\
(0.168)\end{array}$ \\
\hline Wealth index & $\begin{array}{c}0.248 \\
(0.264)\end{array}$ & $\begin{array}{c}0.228 \\
(0.257)\end{array}$ & $\begin{array}{c}0.349 * * \\
(0.165)\end{array}$ & $\begin{array}{c}0.354^{* *} \\
(0.165)\end{array}$ & $\begin{array}{c}0.240 \\
(0.163)\end{array}$ & $\begin{array}{c}0.203 \\
(0.154)\end{array}$ \\
\hline HAZ (lagged, age 1) & & & & & $\begin{array}{c}0.390^{* * * *} \\
(0.044) \\
\end{array}$ & \\
\hline Constant & $\begin{array}{c}-11.28^{* * *} \\
(0.995)\end{array}$ & $\begin{array}{c}-11.40^{* * *} \\
(0.990)\end{array}$ & $\begin{array}{c}-19.11^{* * *} \\
(5.378)\end{array}$ & $\begin{array}{c}-19.19 * * * \\
(5.313)\end{array}$ & $\begin{array}{c}-17.53^{* * *} \\
(5.283)\end{array}$ & $\begin{array}{c}-11.56^{* * * *} \\
(0.817)\end{array}$ \\
\hline Observations & 1319 & 1319 & 1401 & 1401 & 1399 & 1317 \\
\hline R-squared & 0.34 & 0.34 & 0.37 & 0.37 & 0.52 & 0.37 \\
\hline $\begin{array}{l}\text { Note: All controls and community } \\
\text { controls in (6). Mothers with no fo } \\
\text { are clustered at community level. * } \\
\text { education, child's characteristics (a } \\
\text { civic participation, mother's height } \\
\text { community language, household sc } \\
\text { composition (size, composition by } \\
\text { member with disability). }\end{array}$ & $\begin{array}{l}\text { ed effects } \\
l \text { educati } \\
1, * * 0.05 \\
\text { gender, } \\
\text { other em } \\
\text {-econom } \\
\text {, a dumn }\end{array}$ & $\begin{array}{l}\text { included } \\
\text { on as refe } \\
* * * 0.01 \\
\text { thnicity, } \\
\text { ployed fu } \\
\text { ic status } \\
\text { y for inta }\end{array}$ & $\begin{array}{l}\text { ontempo } \\
\text { ce categ } \\
\text { el. Othe } \\
\text { th weigh } \\
\text { me, a du } \\
\text { ocks dun } \\
\text { househo }\end{array}$ & $\begin{array}{l}\text { eous con } \\
\text { Standar } \\
\text { ntrols no } \\
\text { parents' } \\
\text { ny for wh } \\
\text { y, urban/1 }\end{array}$ & $\begin{array}{l}\text { ls in (1) } \\
\text { errors in } \\
\text { eported: } \\
\text { e, materr } \\
\text { her she } \\
\text { al locati } \\
\text { ousehold }\end{array}$ & $\begin{array}{l}\text {; lagged } \\
\text { rentheses } \\
\text { ther's } \\
\text { trust and } \\
\text { aks } \\
\text { and } \\
\text { ousehold }\end{array}$ \\
\hline
\end{tabular}


Table 5: Mechanisms through which the association between maternal group membership and child HAZ might operate

\begin{tabular}{lccccc}
\hline & \multicolumn{2}{c}{ Mother not a member } & \multicolumn{2}{c}{ Mother a member } \\
& Mean & Std.Dev & Mean & Std.Dev & t-test \\
\hline $\begin{array}{l}\text { Child received polio, measles and } \\
\text { BCG vaccines }\end{array}$ & 0.34 & 0.012 & 0.36 & 0.024 & 0.288 \\
Being breastfed (in months) & 10.90 & 0.091 & 11.23 & 0.181 & 0.100 \\
Still being breastfed & 0.87 & 0.008 & 0.85 & 0.018 & 0.229 \\
Mother-child bonding & 1.28 & 0.020 & 1.37 & 0.039 & 0.041 \\
Mother mental & 5.59 & 0.104 & 6.07 & 0.212 & 0.045 \\
health problems ( no. of & & & & & \\
symptoms) & & & & & \\
Mother received support & & & & & \\
Any support & 0.66 & 0.012 & 0.85 & 0.018 & 0.000 \\
Only external support & 0.66 & 0.012 & 0.31 & 0.023 & 0.000 \\
Internal support &. &. & 0.54 & 0.024 &. \\
\hline
\end{tabular}

Note: Maternal group membership is measured at Round 1. Mean values and standard deviations (in parentheses) are reported alongside tests for statistical significant of differences in mean. 
Table 6: Exploring the mechanisms through which the association between maternal group membership and child HAZ might operate

\begin{tabular}{|c|c|c|c|c|c|}
\hline & (1) & (2) & (3) & (4) & $(5)$ \\
\hline Mother's educ: No educ. ${ }^{*}$ member & $\begin{array}{c}0.431 * * \\
(0.203)\end{array}$ & $\begin{array}{c}0.428 * * \\
(0.201)\end{array}$ & $\begin{array}{c}0.434 * \\
(0.207)\end{array}$ & $\begin{array}{c}0.429 * * \\
(0.203)\end{array}$ & $\begin{array}{l}0.412^{*} \\
(0.210)\end{array}$ \\
\hline Mother's educ: Primary*member & $\begin{array}{l}-0.098 \\
(0.150)\end{array}$ & $\begin{array}{c}-0.087 \\
(0.142)\end{array}$ & $\begin{array}{l}-0.102 \\
(0.145)\end{array}$ & $\begin{array}{l}-0.076 \\
(0.142)\end{array}$ & $\begin{array}{c}0.026 \\
(0.168)\end{array}$ \\
\hline Mother's educ: Secondary*member & $\begin{array}{l}-0.149 \\
(0.116)\end{array}$ & $\begin{array}{c}-0.137 \\
(0.111)\end{array}$ & $\begin{array}{c}-0.165 \\
(0.108)\end{array}$ & $\begin{array}{l}-0.149 \\
(0.110)\end{array}$ & $\begin{array}{l}-0.209 \\
(0.122)\end{array}$ \\
\hline Mother's educ: > Secondary*member & $\begin{array}{l}-0.021 \\
(0.214)\end{array}$ & $\begin{array}{c}-0.004 \\
(0.234)\end{array}$ & $\begin{array}{c}0.005 \\
(0.214)\end{array}$ & $\begin{array}{c}0.017 \\
(0.216)\end{array}$ & $\begin{array}{c}0.121 \\
(0.272)\end{array}$ \\
\hline Mother's educ: Primary & $\begin{array}{l}0.424 * \\
(0.231)\end{array}$ & $\begin{array}{c}0.435^{*} \\
(0.225)\end{array}$ & $\begin{array}{c}0.434 * \\
(0.235)\end{array}$ & $\begin{array}{l}0.422 * \\
(0.224)\end{array}$ & $\begin{array}{c}0.381 \\
(0.232)\end{array}$ \\
\hline Mother's educ: Secondary & $\begin{array}{l}0.440^{*} \\
(0.237)\end{array}$ & $\begin{array}{l}0.456^{*} \\
(0.231)\end{array}$ & $\begin{array}{l}0.460 * \\
(0.242)\end{array}$ & $\begin{array}{l}0.445^{*} \\
(0.232)\end{array}$ & $\begin{array}{l}0.448^{*} \\
(0.248)\end{array}$ \\
\hline Mother's educ: > Secondary & $\begin{array}{c}0.482 \\
(0.293)\end{array}$ & $\begin{array}{c}0.469 \\
(0.284)\end{array}$ & $\begin{array}{c}0.463 \\
(0.295)\end{array}$ & $\begin{array}{c}0.455 \\
(0.287)\end{array}$ & $\begin{array}{c}0.362 \\
(0.295)\end{array}$ \\
\hline Received polio, BCG and measles vaccines & $\begin{array}{l}-0.083 \\
(0.107)\end{array}$ & & & & \\
\hline Being breastfed (in months) & & $\begin{array}{c}0.028 * \\
(0.015)\end{array}$ & & & \\
\hline Still being breastfed & & $\begin{array}{c}-0.146 \\
(0.132)\end{array}$ & & & \\
\hline Any support received & & & $\begin{array}{c}0.109 * \\
(0.062)\end{array}$ & & \\
\hline Maternal mental health & & & & $\begin{array}{l}-0.004 \\
(0.006)\end{array}$ & \\
\hline Mother-child bonding & & & & & $\begin{array}{c}0.031 \\
(0.042)\end{array}$ \\
\hline Observations & 1299 & 1303 & 1319 & 1319 & 1065 \\
\hline R-squared & 0.34 & 0.34 & 0.34 & 0.34 & 0.35 \\
\hline
\end{tabular}

Note: All (lagged) controls and community fixed effects included. Mothers with no formal education as reference category. Standard errors in parentheses are clustered at community level. * $0.1, * * 0.05, * * * 0.01$ level. Other controls not reported: father's education, child's characteristics (age, gender, ethnicity, birth weight), parents' age, maternal trust and civic participation, mother's height, mother employed full time, a dummy for whether she speaks community language, household socio-economic status (shocks dummy, wealth index, urban location) and composition (size, composition by age, a dummy for intact household, onechild household, household member with disability). 


\section{Appendix}

Table A1: Definitions of control variables

\begin{tabular}{|c|c|}
\hline Maternal civic participation & $\begin{array}{l}\text { This is an ordered variable taking the value } 0 \\
\text { if in the past } 12 \text { months the respondent has } \\
\text { not joined with others in the community to } \\
\text { address a particular issue and/or has not } \\
\text { contacted the local authority about problems } \\
\text { in the community. Otherwise, it takes value } 1 \\
\text { if she did only one of these two things and } 2 \\
\text { if she did both. }\end{array}$ \\
\hline Maternal sense of trust and belonging & $\begin{array}{l}\text { The variable takes a value between } 0 \text { and } 4 \\
\text { and it is constructed by summing together } \\
\text { the following Round } 1 \text { questions: whether } \\
\text { the caregiver feels herself to be part of the } \\
\text { community, whether she feels people in } \\
\text { general can be trusted, whether she feels } \\
\text { people generally get along with each other, } \\
\text { and whether she thinks people would try } \\
\text { and take advantage of her if they could. }\end{array}$ \\
\hline Wealth Index & $\begin{array}{l}\text { This is a composite measure of living } \\
\text { standards. It is the simple average of three } \\
\text { sub-indexes: a housing quality index (quality } \\
\text { of floor, wall, roof and number of rooms per } \\
\text { capita), an access to services index (access to } \\
\text { drinking water, electricity, sewage and fuel } \\
\text { used for cooking) and a consumer durables } \\
\text { index (TV, radio, fridge, microwave, } \\
\text { computer, etc). The wealth index for each } \\
\text { household is a score between } 0 \text { and } 1 \text {. }\end{array}$ \\
\hline Shocks & $\begin{array}{l}\text { A dummy variable equal to } 1 \text { if the household } \\
\text { has suffered at least one shock (e.g. natural } \\
\text { disaster, death in the family or crop failure) in } \\
\text { the last } 12 \text { months (in Round } 1 \text { ) or in the past } \\
\text { four years/since the previous data collection } \\
\text { round (in Round } 2 \text { ) and } 0 \text { otherwise }\end{array}$ \\
\hline Maternal and paternal education & $\begin{array}{l}\text { These are defined by a set of four dummies } \\
\text { identifying those individuals with: (a) no } \\
\text { formal education, (b) primary or incomplete } \\
\text { primary education, (c) secondary or } \\
\text { incomplete secondary education and (d) more } \\
\text { than secondary education. }\end{array}$ \\
\hline Birth weight & $\begin{array}{l}\text { Provided by the mother in Round } 1 \text { and } \\
\text { verified with documentation where possible. } \\
\text { It is recorded in grams. }\end{array}$ \\
\hline Maternal height & This was collected in Round 1. It is recorded \\
\hline
\end{tabular}




\begin{tabular}{|c|c|}
\hline & in centimetres. \\
\hline Ethnicity & $\begin{array}{l}\text { This covers three ethnic categories: white, } \\
\text { mestizo (reference category) or other. }\end{array}$ \\
\hline Language & $\begin{array}{l}\text { This is a dummy equal to } 1 \text { if the mother } \\
\text { speaks the most common language used in } \\
\text { the community and equal to } 0 \text { otherwise. }\end{array}$ \\
\hline Employment status & $\begin{array}{l}\text { This is a dummy variable equal to } 1 \text { if the } \\
\text { mother is employed full time, i.e. if she is } \\
\text { paid to work outside the household for six } \\
\text { or seven days per week, and zero } \\
\text { otherwise. }\end{array}$ \\
\hline Maternal mental health & $\begin{array}{l}\text { In Rounds } 1 \text { and } 2 \text { Young Lives administer } \\
\text { the Self-Reporting Questionnaire } 20 \text { (SRQ- } \\
\text { 20). The SRQ-20 is a screening tool for } \\
\text { common mental disorders designed by the } \\
\text { WHO for use in low income countries } \\
\text { (WHO, 1994). Respondents are asked to } \\
\text { answer } 20 \text { yes/no questions relating to } \\
\text { symptoms of depression and anxiety that } \\
\text { they have experienced in the past } 30 \text { days. } \\
\text { The variable used in the analysis is the } \\
\text { number of symptoms reported by the } \\
\text { mother. }\end{array}$ \\
\hline Mother-child bonding & $\begin{array}{l}\text { The interviewer asks to the mother what } \\
\text { she does and how she reacts when the } \\
\text { child will not stop crying: she holds } \\
\text { him/her, she soothes him/her, she sings to } \\
\text { him/her or she gives him/her water to calm } \\
\text { him/her ('good practices') or she smacks } \\
\text { him/her, she shakes him/her, she threatens } \\
\text { him/her, she lets him/her cry until he/she } \\
\text { falls asleep ('bad practices'). She is asked } \\
\text { to report all the options that apply. This is } \\
\text { the procedure adopted to compute the } \\
\text { parenting: (i) all 'good practices' are coded } \\
\text { as } 1 \text { and all 'bad practices' re coded as -1; } \\
\text { (ii) the indicator is therefore computed as } \\
\text { the difference between good and bad } \\
\text { practices. The higher the score is the more } \\
\text { the mother is able to tune into and respond } \\
\text { to her child's cries and distress in a warm } \\
\text { and sensitive way. }\end{array}$ \\
\hline Others & $\begin{array}{l}\text { Other variables included in the models are: } \\
\text { child gender (male), child's age (in } \\
\text { months) and both parents' ages (in years); } \\
\text { household size and household composition }\end{array}$ \\
\hline
\end{tabular}




\begin{tabular}{|c|c|c|}
\hline & & $\begin{array}{l}\text { (a dummy equal to } 1 \text { if the Young Lives } \\
\text { child is the only child living in the } \\
\text { household; the number of household } \\
\text { members younger than } 2 \text {, between } 2 \text { and } 5 \\
\text { years old and between } 5 \text { and } 14 \text { years old); } \\
\text { and a dummy equal to } 1 \text { if any household } \\
\text { member has a mental or physical disability. }\end{array}$ \\
\hline
\end{tabular}


Table A2: Child HAZ at the ages of 1 and 5

\begin{tabular}{|c|c|c|c|c|c|c|}
\hline & \multicolumn{2}{|c|}{ HAZ at age 1} & \multicolumn{3}{|c|}{ HAZ at age 5} & \multirow[b]{2}{*}{ (6) } \\
\hline & (1) & (2) & (3) & (4) & $(5)$ & \\
\hline Member of at least one organization & $\begin{array}{l}-0.067 \\
(0.089)\end{array}$ & & $\begin{array}{l}-0.005 \\
(0.054)\end{array}$ & & & \\
\hline Mother's educ: No educ.*member & & $\begin{array}{c}0.431 * * \\
(0.196)\end{array}$ & & $\begin{array}{c}-0.135 \\
(0.093)\end{array}$ & $\begin{array}{l}-0.242 \\
(0.163)\end{array}$ & $\begin{array}{c}0.075 \\
(0.165)\end{array}$ \\
\hline Mother's educ: Primary*member & & $\begin{array}{c}-0.080 \\
(0.142)\end{array}$ & & $\begin{array}{l}-0.037 \\
(0.088)\end{array}$ & $\begin{array}{c}0.006 \\
(0.082)\end{array}$ & $\begin{array}{c}-0.073 \\
(0.082)\end{array}$ \\
\hline Mother's educ: Secondary*member & & $\begin{array}{l}-0.148 \\
(0.112)\end{array}$ & & $\begin{array}{c}0.010 \\
(0.079)\end{array}$ & $\begin{array}{c}0.028 \\
(0.076)\end{array}$ & $\begin{array}{c}-0.133 \\
(0.080)\end{array}$ \\
\hline Mother's educ: >Secondary*member & & $\begin{array}{c}0.021 \\
(0.213)\end{array}$ & & $\begin{array}{c}0.072 \\
(0.104)\end{array}$ & $\begin{array}{c}0.064 \\
(0.089)\end{array}$ & $\begin{array}{c}-0.094 \\
(0.187)\end{array}$ \\
\hline Mother's educ: Primary & $\begin{array}{c}0.344 \\
(0.212)\end{array}$ & $\begin{array}{c}0.428^{*} \\
(0.229)\end{array}$ & $\begin{array}{c}0.100 \\
(0.137)\end{array}$ & $\begin{array}{c}0.082 \\
(0.146)\end{array}$ & $\begin{array}{c}-0.035 \\
(0.101)\end{array}$ & $\begin{array}{c}0.222 \\
(0.139)\end{array}$ \\
\hline Mother's educ: Secondary & $\begin{array}{c}0.353 \\
(0.226)\end{array}$ & $\begin{array}{c}0.454^{*} \\
(0.236)\end{array}$ & $\begin{array}{l}0.273^{*} \\
(0.139)\end{array}$ & $\begin{array}{c}0.245 \\
(0.151)\end{array}$ & $\begin{array}{c}0.127 \\
(0.097)\end{array}$ & $\begin{array}{c}0.400 * * \\
(0.149)\end{array}$ \\
\hline Mother's educ: >Secondary & $\begin{array}{c}0.405 \\
(0.280)\end{array}$ & $\begin{array}{c}0.468 \\
(0.292)\end{array}$ & $\begin{array}{c}0.258 \\
(0.159)\end{array}$ & $\begin{array}{c}0.217 \\
(0.177)\end{array}$ & $\begin{array}{c}0.082 \\
(0.136)\end{array}$ & $\begin{array}{c}0.356^{* *} \\
(0.168)\end{array}$ \\
\hline Height-for-age (lagged, age 1) & & & & & $\begin{array}{c}0.390 * * * \\
(0.044)\end{array}$ & \\
\hline Father's educ: Primary & $\begin{array}{c}0.215 \\
(0.200)\end{array}$ & $\begin{array}{c}0.211 \\
(0.199)\end{array}$ & $\begin{array}{c}0.318 \\
(0.208)\end{array}$ & $\begin{array}{c}0.317 \\
(0.206)\end{array}$ & $\begin{array}{c}0.261^{*} \\
(0.151)\end{array}$ & $\begin{array}{c}0.348 \\
(0.217)\end{array}$ \\
\hline Father's educ: Secondary & $\begin{array}{c}0.236 \\
(0.216)\end{array}$ & $\begin{array}{c}0.234 \\
(0.215)\end{array}$ & $\begin{array}{c}0.378 \\
(0.220)\end{array}$ & $\begin{array}{l}0.377^{*} \\
(0.218)\end{array}$ & $\begin{array}{c}0.305^{*} \\
(0.158)\end{array}$ & $\begin{array}{c}0.407^{*} \\
(0.226)\end{array}$ \\
\hline Father's educ: >Secondary & $\begin{array}{c}0.308 \\
(0.221)\end{array}$ & $\begin{array}{c}0.307 \\
(0.219)\end{array}$ & $\begin{array}{c}0.521 * * \\
(0.218)\end{array}$ & $\begin{array}{l}0.522^{* *} \\
(0.217)\end{array}$ & $\begin{array}{l}0.402 * * \\
(0.164)\end{array}$ & $\begin{array}{c}0.539 * * \\
(0.226)\end{array}$ \\
\hline Mother's Trust & $\begin{array}{l}-0.008 \\
(0.033)\end{array}$ & $\begin{array}{c}-0.010 \\
(0.033)\end{array}$ & & & & $\begin{array}{c}-0.024 \\
(0.032)\end{array}$ \\
\hline Mother's civic participation & $\begin{array}{l}-0.030 \\
(0.035)\end{array}$ & $\begin{array}{c}-0.037 \\
(0.037)\end{array}$ & & & & $\begin{array}{c}-0.072 * * * \\
(0.023)\end{array}$ \\
\hline Wealth index & $\begin{array}{c}0.248 \\
(0.264)\end{array}$ & $\begin{array}{c}0.228 \\
(0.257)\end{array}$ & $\begin{array}{c}0.349 * * \\
(0.165)\end{array}$ & $\begin{array}{l}0.354 * * \\
(0.165)\end{array}$ & $\begin{array}{c}0.240 \\
(0.163)\end{array}$ & $\begin{array}{c}0.203 \\
(0.154)\end{array}$ \\
\hline Child: age (in months) & $\begin{array}{c}-0.085 \\
(0.087)\end{array}$ & $\begin{array}{l}-0.085 \\
(0.088)\end{array}$ & $\begin{array}{c}0.260 \\
(0.167)\end{array}$ & $\begin{array}{c}0.263 \\
(0.165)\end{array}$ & $\begin{array}{c}0.323^{*} \\
(0.169)\end{array}$ & $\begin{array}{c}0.032 \\
(0.073)\end{array}$ \\
\hline Child: age squared & $\begin{array}{l}-0.000 \\
(0.004)\end{array}$ & $\begin{array}{c}-0.000 \\
(0.004)\end{array}$ & $\begin{array}{l}-0.002 \\
(0.001)\end{array}$ & $\begin{array}{c}-0.002 \\
(0.001)\end{array}$ & $\begin{array}{l}-0.002 * \\
(0.001)\end{array}$ & $\begin{array}{c}-0.001 \\
(0.003)\end{array}$ \\
\hline Child: Birth weight (kg) & $\begin{array}{c}0.551 * * * \\
(0.053)\end{array}$ & $\begin{array}{c}0.549 * * * \\
(0.055)\end{array}$ & $\begin{array}{c}0.246 * * * \\
(0.043)\end{array}$ & $\begin{array}{c}0.244 * * * \\
(0.044)\end{array}$ & $\begin{array}{c}0.029 \\
(0.048)\end{array}$ & $\begin{array}{c}0.262 * * * \\
(0.051)\end{array}$ \\
\hline
\end{tabular}




\begin{tabular}{|c|c|c|c|c|c|c|}
\hline Child: Male & $\begin{array}{c}-0.006 \\
(0.071)\end{array}$ & $\begin{array}{c}-0.007 \\
(0.070)\end{array}$ & $\begin{array}{c}-0.070 \\
(0.046)\end{array}$ & $\begin{array}{c}-0.070 \\
(0.046)\end{array}$ & $\begin{array}{c}-0.076^{* *} \\
(0.032)\end{array}$ & $\begin{array}{l}-0.077 * \\
(0.044)\end{array}$ \\
\hline \multirow[t]{2}{*}{ Child: Ethnicity (White) } & -0.117 & -0.118 & -0.030 & -0.030 & 0.022 & -0.036 \\
\hline & $(0.114)$ & $(0.112)$ & $(0.092)$ & $(0.091)$ & $(0.078)$ & $(0.102)$ \\
\hline \multirow[t]{2}{*}{ Child: Ethnicity (Others) } & -0.148 & -0.142 & 0.118 & 0.113 & $0.186 * * *$ & 0.120 \\
\hline & $(0.236)$ & $(0.232)$ & $(0.120)$ & $(0.121)$ & $(0.065)$ & $(0.097)$ \\
\hline \multirow[t]{2}{*}{ Mother: age } & 0.039 & 0.044 & 0.025 & 0.026 & 0.009 & 0.043 \\
\hline & $(0.036)$ & $(0.034)$ & $(0.042)$ & $(0.042)$ & $(0.038)$ & $(0.042)$ \\
\hline \multirow[t]{2}{*}{ Mother: age squared } & -0.001 & -0.001 & -0.000 & -0.000 & -0.000 & -0.000 \\
\hline & $(0.001)$ & $(0.001)$ & $(0.001)$ & $(0.001)$ & $(0.001)$ & $(0.001)$ \\
\hline \multirow[t]{2}{*}{ Mother's height } & $0.050^{* * *}$ & $0.050 * * *$ & $0.046 * * *$ & $0.046^{* * *}$ & $0.026 * * *$ & $0.045 * * *$ \\
\hline & $(0.005)$ & $(0.005)$ & $(0.004)$ & $(0.004)$ & $(0.005)$ & $(0.005)$ \\
\hline \multirow{2}{*}{ Mother employed full-time } & $0.285^{*}$ & $0.281 *$ & -0.035 & -0.035 & -0.049 & $0.420 * * *$ \\
\hline & $(0.147)$ & $(0.143)$ & $(0.066)$ & $(0.066)$ & $(0.053)$ & $(0.139)$ \\
\hline \multirow[t]{2}{*}{ Father: age } & 0.037 & 0.034 & 0.036 & 0.035 & 0.030 & $0.042 * *$ \\
\hline & $(0.029)$ & $(0.029)$ & $(0.022)$ & $(0.021)$ & $(0.020)$ & $(0.019)$ \\
\hline \multirow[t]{2}{*}{ Father: age squared } & -0.001 & -0.001 & -0.000 & -0.000 & -0.000 & $-0.001 *$ \\
\hline & $(0.000)$ & $(0.000)$ & $(0.000)$ & $(0.000)$ & $(0.000)$ & $(0.000)$ \\
\hline \multirow[t]{2}{*}{ Urban } & -0.135 & -0.130 & -0.059 & -0.054 & -0.031 & 0.050 \\
\hline & $(0.084)$ & $(0.086)$ & $(0.076)$ & $(0.075)$ & $(0.076)$ & $(0.067)$ \\
\hline \multirow[t]{2}{*}{ Any shocks } & -0.017 & -0.016 & 0.068 & 0.069 & 0.020 & 0.029 \\
\hline & $(0.046)$ & $(0.046)$ & $(0.052)$ & $(0.052)$ & $(0.046)$ & $(0.050)$ \\
\hline \multirow[t]{2}{*}{ Speak community language } & 0.060 & 0.058 & 0.049 & 0.051 & 0.026 & -0.008 \\
\hline & $(0.091)$ & (0.089) & $(0.058)$ & $(0.060)$ & $(0.046)$ & (0.090) \\
\hline \multirow[t]{2}{*}{ One-child household } & -0.065 & -0.061 & 0.021 & 0.020 & 0.072 & $0.202 * *$ \\
\hline & $(0.110)$ & $(0.110)$ & $(0.071)$ & $(0.071)$ & $(0.077)$ & $(0.077)$ \\
\hline \multirow[t]{2}{*}{ Household size } & $0.076 * * *$ & $0.077 * * *$ & -0.019 & -0.018 & -0.004 & 0.021 \\
\hline & $(0.024)$ & $(0.024)$ & $(0.018)$ & $(0.018)$ & $(0.013)$ & $(0.018)$ \\
\hline \multirow{2}{*}{ N. of children aged $\leq 2$} & $-0.267 * *$ & $-0.268 * *$ & 0.022 & 0.020 & -0.021 & $-0.209 * *$ \\
\hline & $(0.118)$ & $(0.120)$ & $(0.070)$ & $(0.070)$ & $(0.053)$ & $(0.097)$ \\
\hline \multirow[t]{2}{*}{ N. of $2<$ children aged $\leq 5$} & $-0.243 * * *$ & $-0.246^{* * *}$ & -0.018 & -0.019 & 0.016 & $-0.160 * * *$ \\
\hline & $(0.057)$ & $(0.058)$ & $(0.064)$ & $(0.065)$ & $(0.048)$ & $(0.051)$ \\
\hline \multirow[t]{2}{*}{ N. of $5<$ children aged $\leq 14$} & $-0.155 * *$ & $-0.157 * *$ & $-0.143^{* * *}$ & $-0.144 * * *$ & $-0.105^{* * *}$ & $-0.087 * *$ \\
\hline & $(0.056)$ & $(0.056)$ & $(0.027)$ & $(0.027)$ & $(0.021)$ & $(0.039)$ \\
\hline \multirow{2}{*}{$\begin{array}{l}\text { Household member } \\
\text { disability }\end{array}$} & $-0.187 * *$ & $-0.185^{* *}$ & -0.099 & -0.102 & -0.031 & -0.099 \\
\hline & $(0.069)$ & $(0.069)$ & $(0.076)$ & $(0.078)$ & $(0.069)$ & $(0.062)$ \\
\hline Constant & $\begin{array}{c}-11.285 * * * \\
(0.995)\end{array}$ & $\begin{array}{c}-11.405^{* * *} \\
(0.990)\end{array}$ & $\begin{array}{c}-19.112 * * * \\
(5.378)\end{array}$ & $\begin{array}{c}-19.196 * * * \\
(5.313)\end{array}$ & $\begin{array}{c}-17.536 * * * \\
(5.283)\end{array}$ & $\begin{array}{c}-11.563 * * * * \\
(0.817)\end{array}$ \\
\hline Observations & 1319 & 1319 & 1401 & 1401 & 1399 & 1317 \\
\hline $\mathrm{R}$-squared & 0.34 & 0.34 & 0.37 & 0.37 & 0.52 & 0.37 \\
\hline
\end{tabular}

Note: All controls and community fixed effects included. Contemporaneous controls in (1)-(5); lagged controls in (6). Mothers with no formal education as reference category. Standard errors in parentheses are clustered at community level. * $0.1, * * 0.05, * * * 0.01$ level. 
Table A3: Exploring the mechanisms through which the correlation between maternal group membership and child's HAZ might operate

\begin{tabular}{|c|c|c|c|c|c|}
\hline & (1) & (2) & (3) & (4) & (5) \\
\hline Mother's educ: No educ. ${ }^{*}$ member & $\begin{array}{c}0.431 * * \\
(0.203)\end{array}$ & $\begin{array}{c}0.428 * * \\
(0.201)\end{array}$ & $\begin{array}{l}0.434 * \\
(0.207)\end{array}$ & $\begin{array}{c}0.429 * * \\
(0.203)\end{array}$ & $\begin{array}{c}0.412^{*} \\
(0.210)\end{array}$ \\
\hline Mother's educ: Primary*member & $\begin{array}{l}-0.098 \\
(0.150)\end{array}$ & $\begin{array}{l}-0.087 \\
(0.142)\end{array}$ & $\begin{array}{l}-0.102 \\
(0.145)\end{array}$ & $\begin{array}{c}-0.076 \\
(0.142)\end{array}$ & $\begin{array}{c}0.026 \\
(0.168)\end{array}$ \\
\hline Mother's educ: Secondary*member & $\begin{array}{l}-0.149 \\
(0.116)\end{array}$ & $\begin{array}{l}-0.137 \\
(0.111)\end{array}$ & $\begin{array}{l}-0.165 \\
(0.108)\end{array}$ & $\begin{array}{c}-0.149 \\
(0.110)\end{array}$ & $\begin{array}{l}-0.209 \\
(0.122)\end{array}$ \\
\hline Mother's educ: >Secondary*member & $\begin{array}{l}-0.021 \\
(0.214)\end{array}$ & $\begin{array}{c}-0.004 \\
(0.234)\end{array}$ & $\begin{array}{c}0.005 \\
(0.214)\end{array}$ & $\begin{array}{c}0.017 \\
(0.216)\end{array}$ & $\begin{array}{c}0.121 \\
(0.272)\end{array}$ \\
\hline Mother's educ: Primary & $\begin{array}{l}0.424 * \\
(0.231)\end{array}$ & $\begin{array}{c}0.435^{*} \\
(0.225)\end{array}$ & $\begin{array}{l}0.434^{*} \\
(0.235)\end{array}$ & $\begin{array}{c}0.422^{*} \\
(0.224)\end{array}$ & $\begin{array}{c}0.381 \\
(0.232)\end{array}$ \\
\hline Mother's educ: Secondary & $\begin{array}{c}0.440^{*} \\
(0.237)\end{array}$ & $\begin{array}{c}0.456^{*} \\
(0.231)\end{array}$ & $\begin{array}{l}0.460^{*} \\
(0.242)\end{array}$ & $\begin{array}{c}0.445^{*} \\
(0.232)\end{array}$ & $\begin{array}{c}0.448^{*} \\
(0.248)\end{array}$ \\
\hline Mother's educ: $>$ Secondary & $\begin{array}{c}0.482 \\
(0.293)\end{array}$ & $\begin{array}{c}0.469 \\
(0.284)\end{array}$ & $\begin{array}{c}0.463 \\
(0.295)\end{array}$ & $\begin{array}{c}0.455 \\
(0.287)\end{array}$ & $\begin{array}{c}0.362 \\
(0.295)\end{array}$ \\
\hline Received polio,BCG and measles vaccines & $\begin{array}{l}-0.083 \\
(0.107)\end{array}$ & & & & \\
\hline Being breastfed (in months) & & $\begin{array}{c}0.028^{*} \\
(0.015)\end{array}$ & & & \\
\hline Still being breastfed & & $\begin{array}{l}-0.146 \\
(0.132)\end{array}$ & & & \\
\hline Any support received & & & $\begin{array}{l}0.109^{*} \\
(0.062)\end{array}$ & & \\
\hline Maternal mental health & & & & $\begin{array}{l}-0.004 \\
(0.006)\end{array}$ & \\
\hline Parenting style & & & & & $\begin{array}{c}0.031 \\
(0.042)\end{array}$ \\
\hline Father's educ: Primary & $\begin{array}{c}0.170 \\
(0.196)\end{array}$ & $\begin{array}{c}0.227 \\
(0.192)\end{array}$ & $\begin{array}{c}0.198 \\
(0.191)\end{array}$ & $\begin{array}{c}0.221 \\
(0.195)\end{array}$ & $\begin{array}{c}0.254 \\
(0.215)\end{array}$ \\
\hline Father's educ: Secondary & $\begin{array}{c}0.219 \\
(0.218)\end{array}$ & $\begin{array}{c}0.239 \\
(0.210)\end{array}$ & $\begin{array}{c}0.220 \\
(0.209)\end{array}$ & $\begin{array}{c}0.248 \\
(0.209)\end{array}$ & $\begin{array}{c}0.304 \\
(0.237)\end{array}$ \\
\hline Father's educ: $>$ Secondary & $\begin{array}{c}0.275 \\
(0.212)\end{array}$ & $\begin{array}{c}0.305 \\
(0.214)\end{array}$ & $\begin{array}{c}0.296 \\
(0.213)\end{array}$ & $\begin{array}{c}0.324 \\
(0.213)\end{array}$ & $\begin{array}{c}0.360 \\
(0.236)\end{array}$ \\
\hline Mother's Trust & $\begin{array}{l}-0.001 \\
(0.032)\end{array}$ & $\begin{array}{l}-0.008 \\
(0.032)\end{array}$ & $\begin{array}{l}-0.008 \\
(0.032)\end{array}$ & $\begin{array}{c}-0.008 \\
(0.033)\end{array}$ & $\begin{array}{l}-0.014 \\
(0.043)\end{array}$ \\
\hline Mother's Civic participation & $\begin{array}{l}-0.033 \\
(0.037)\end{array}$ & $\begin{array}{l}-0.036 \\
(0.039)\end{array}$ & $\begin{array}{l}-0.035 \\
(0.037)\end{array}$ & $\begin{array}{c}-0.035 \\
(0.037)\end{array}$ & $\begin{array}{l}-0.013 \\
(0.046)\end{array}$ \\
\hline Wealth index & $\begin{array}{c}0.288 \\
(0.246)\end{array}$ & $\begin{array}{c}0.253 \\
(0.255)\end{array}$ & $\begin{array}{c}0.213 \\
(0.254)\end{array}$ & $\begin{array}{c}0.225 \\
(0.254)\end{array}$ & $\begin{array}{c}0.344 \\
(0.289)\end{array}$ \\
\hline Child: age (in months) & $\begin{array}{l}-0.085 \\
(0.088)\end{array}$ & $\begin{array}{l}-0.111 \\
(0.094)\end{array}$ & $\begin{array}{l}-0.084 \\
(0.088)\end{array}$ & $\begin{array}{c}-0.084 \\
(0.088)\end{array}$ & $\begin{array}{l}-0.050 \\
(0.103)\end{array}$ \\
\hline Child: age squared & $\begin{array}{c}0.000 \\
(0.004)\end{array}$ & $\begin{array}{c}-0.000 \\
(0.004)\end{array}$ & $\begin{array}{c}-0.000 \\
(0.004)\end{array}$ & $\begin{array}{l}-0.000 \\
(0.004)\end{array}$ & $\begin{array}{l}-0.002 \\
(0.004)\end{array}$ \\
\hline Child: Birth weight (kg) & $\begin{array}{c}0.549 * * * \\
(0.055)\end{array}$ & $\begin{array}{c}0.568 * * * \\
(0.057)\end{array}$ & $\begin{array}{c}0.551^{* * *} \\
(0.055)\end{array}$ & $\begin{array}{c}0.550 * * * \\
(0.055)\end{array}$ & $\begin{array}{c}0.554 * * * \\
(0.056)\end{array}$ \\
\hline
\end{tabular}


Child: Male

Child: Ethnicity (White)

Child: Ethnicity (Others)

Mother: age

Mother: age squared

Mother's height

Mother employed full-time

Father: age

Father: age squared

Urban

Any shocks

Speak community language

One-child household

Household size

N. of children aged $\leq 2$

N. of $2<$ children aged $\leq 5$

N. of $5<$ children aged $\leq 14$

Household member with disability

\begin{tabular}{|c|c|c|c|c|}
\hline $\begin{array}{c}0.083 \\
(0.052)\end{array}$ & $\begin{array}{c}0.069 \\
(0.052)\end{array}$ & $\begin{array}{c}0.077 \\
(0.050)\end{array}$ & $\begin{array}{c}0.078 \\
(0.049)\end{array}$ & $\begin{array}{l}0.102 * \\
(0.054)\end{array}$ \\
\hline-0.136 & -0.146 & -0.126 & -0.126 & -0.126 \\
\hline (0.119) & $(0.115)$ & $(0.111)$ & $(0.110)$ & $(0.109)$ \\
\hline-0.187 & -0.094 & -0.147 & -0.155 & -0.190 \\
\hline$(0.250)$ & $(0.252)$ & $(0.233)$ & $(0.236)$ & $(0.216)$ \\
\hline 0.045 & 0.047 & 0.045 & 0.046 & 0.034 \\
\hline$(0.037)$ & $(0.034)$ & $(0.034)$ & $(0.034)$ & $(0.039)$ \\
\hline-0.001 & -0.001 & -0.001 & -0.001 & -0.001 \\
\hline$(0.001)$ & $(0.001)$ & $(0.001)$ & $(0.001)$ & $(0.001)$ \\
\hline $0.051 * * *$ & $0.050 * * *$ & $0.050 * * *$ & $0.050 * * *$ & $0.055^{* * *}$ \\
\hline$(0.005)$ & $(0.005)$ & $(0.005)$ & $(0.005)$ & $(0.006)$ \\
\hline 0.253 & $0.272 *$ & $0.264 *$ & $0.272 *$ & $0.343 * *$ \\
\hline$(0.149)$ & $(0.146)$ & $(0.145)$ & $(0.145)$ & $(0.154)$ \\
\hline 0.034 & 0.033 & 0.035 & 0.033 & 0.040 \\
\hline$(0.029)$ & $(0.028)$ & $(0.028)$ & $(0.028)$ & $(0.033)$ \\
\hline-0.001 & -0.001 & -0.001 & -0.001 & -0.001 \\
\hline$(0.000)$ & $(0.000)$ & $(0.000)$ & $(0.000)$ & $(0.000)$ \\
\hline$-0.153 *$ & -0.126 & -0.131 & -0.127 & $-0.202 * * *$ \\
\hline$(0.086)$ & $(0.086)$ & $(0.082)$ & $(0.086)$ & $(0.070)$ \\
\hline-0.010 & -0.013 & -0.028 & -0.011 & -0.017 \\
\hline$(0.049)$ & $(0.047)$ & $(0.049)$ & $(0.049)$ & $(0.076)$ \\
\hline 0.009 & 0.051 & 0.059 & 0.056 & 0.022 \\
\hline$(0.084)$ & $(0.088)$ & $(0.088)$ & $(0.088)$ & $(0.099)$ \\
\hline-0.067 & -0.051 & -0.060 & -0.060 & -0.082 \\
\hline$(0.117)$ & $(0.113)$ & (0.109) & $(0.110)$ & $(0.129)$ \\
\hline $0.074 * * *$ & $0.080 * * *$ & $0.078 * * *$ & $0.076 * * *$ & $0.065^{* *}$ \\
\hline$(0.023)$ & $(0.023)$ & $(0.024)$ & $(0.024)$ & $(0.024)$ \\
\hline$-0.281 * *$ & $-0.265 * *$ & $-0.272 * *$ & $-0.267 * *$ & $-0.296^{*}$ \\
\hline$(0.127)$ & $(0.123)$ & $(0.121)$ & $(0.121)$ & $(0.150)$ \\
\hline$-0.248 * * *$ & $-0.246 * * *$ & $-0.244 * * *$ & $-0.246 * * *$ & $-0.224 * * *$ \\
\hline$(0.060)$ & $(0.059)$ & $(0.058)$ & $(0.057)$ & $(0.073)$ \\
\hline$-0.152 * *$ & $-0.160 * * *$ & $-0.158 * *$ & $-0.154 * *$ & $-0.143 * *$ \\
\hline$(0.055)$ & $(0.054)$ & $(0.055)$ & $(0.055)$ & $(0.056)$ \\
\hline$-0.167 * *$ & $-0.187 * *$ & $-0.196 * *$ & $-0.178 * *$ & $-0.204 *$ \\
\hline$(0.067)$ & $(0.068)$ & $(0.070)$ & $(0.071)$ & $(0.099)$ \\
\hline$-11.621 * * *$ & $-11.422 * * *$ & $-11.569 * * *$ & $-11.502 * * *$ & $-12.337 * * *$ \\
\hline (1.008) & (1.032) & $(0.974)$ & $(0.996)$ & (1.193) \\
\hline 1299 & 1303 & 1319 & 1319 & 1065 \\
\hline 0.34 & 0.34 & 0.34 & 0.34 & 0.35 \\
\hline
\end{tabular}

Constant

Observations

R-squared

Note: All (lagged) controls and community fixed effect included. Mothers with no formal education as reference category. Standard errors in parentheses are clustered at community level. * 0.1,**0.05, $* * * 0.01$ level. 